\title{
Developing Creative Economy for Community Learners in Supporting Tourism in Tembok and Abang Village, Bali
}

\author{
I Ketut Sudita ${ }^{1}$, Dewa Nyoman Sudana ${ }^{2}$, Nengah Suandi ${ }^{3}$, Dewa Bagus Sanjaya ${ }^{4}$ \\ Education of Fine Arts ${ }^{1}$, Primary Teacher Education ${ }^{2}$, Indonesian Language and Literature Education ${ }^{3}$, Civic Education ${ }^{4}$ \\ ${ }_{1,2,3,4}$ Universitas Pendidikan Ganesha \\ Singaraja, Indonesia \\ ketut.sudita@undiksha.ac.id ${ }^{1}$,dewanyoman.sudana@undiksha.ac.id ${ }^{2}$,nengah.suandi@undiksha.ac.id ${ }^{3}$, \\ bagus.sanjaya@undiksha.ac.id ${ }^{4}$
}

\begin{abstract}
Community group learners are a community group that sets an example and deserves to be given a priority in a program for strengthening and extending economy, especially in Bali province. Departing from this idea, this study was aimed (1) to produce an innovative design for handicrafs (creative economy) for community group learners which matches their existing potentialities, (2) to produce a creative economy strategy at a larger scale. The results of this study showed that the craftsmen had been able to produce various handicrafts such as laptop baggage, sokasi (bamboo basketwork used for holding rice), ballpoint stand, bamboo basket or tray for keeping offerings with a variety of designs. Community learners were able to develop product to meet the market conditions and demands and were able to develop a larger network, with the local government, universities, and businesses.
\end{abstract}

\section{Keywords - community learners, creative economy, tourism}

\section{INTRODUCTION}

Suparwoko states that a synergy between creative economy and tourism sector is a model for developing economy which is potential enough to be developed in Indonesia, including Bali province. To develop creative economy as a motivating sector of tourism there is a need for creativity, that is, by creating outlets for creative products in a strategic location and near a tourist location. The outlets can be counters or handicraft center which are not just places for buying souvenirs, but also places to see the process of making them and even tourists can participate in making them [1]. Sujana states that the development and improvement of creative economy in a larger scale involve community learners from other villages. In addition, the products produced by them have been accepted by partner businesses as ready to export commodities [2 and 3].

In 2010, April [4] did a study about the increase in the productivity of fan group through training on graphic design aiming at improving community members' ability in creating various designs through computer. Hence, the community of craftsmen will be more creative, not only in designing drawings with computer technology but also understand how to draw good and interesting drawings to be uploaded in the internet through web. Based on the result of a research done by Heni, there are two classifications of woodcraftsmen groups, namely applied craftsmen group ( furniture and household tools) and non-applied one ( souvenirs and ornaments) [5].

Creative economy is one of the supporting and very important factors which form moving spirits in tourism sector. As firmly stated in Article 1 No. 2 Act No. 10 of 2009 tourism is a variety of tourism activities and is supported by a variety of facilities and services provided by the community, business people, the central government, and local government. Tourism is one of the needs in human life. It is done by individuals, families, groups, and social organizations. In general, conventional tourists visit natural tourist objects, cultural objects, and objects for special interests. Tourist objects are supported by three main elements, namely (1) main tourism superstructure which comprises travel agents, transportation, restaurants, tourist objects and tourist attractions, (2) supplementing tourism or facilities to supplement tourism facilities which comprise recreational and sports facilities and public facilities such as main roads, bridges, electricity, airport, telecommunication, clean water, and harbors, (3) supporting tourism superstructure which comprises night life, entertainment, mailing service, and souvenir shops.

The Department of Commerce of the Republic of Indonesia formulates creative economy as an effort to develop economy in a sustainable way through creativity with an economic condition which is competitive and has renewable resources [6]. The Department of Commerce identifies at least 14 sectors which belong to creative economy. They are (1) advertisement, (2) architecture, (3) art products market, (4) handicraft, (5) design, (6) fashion, (7) film, video, and photography, (8) interactive games, (9) music, (10) performing arts, (11) publication and printing, (12)computer and software services, (13) radio and television, (14) research and development.

Autonomous business literacy is the basic ability or skill which is taught through productive and livelihood training which can improve the literacy and income of the participants, both as individual and groups as a way to strengthen the literacy and at the same time reducing poverty.

One Village One Product (OVOP) is an effort made by the government to increase added value of the local products 
which are considered superior in the effort to increase the prosperity of the community through cooperatives or small and medium scale businesses. The criteria of the OVOP program are : (a). It is a product which is considered as superior product of the local area that has been developed from generation to generation; (b) It is a special product of the local area; (c) It is based on local resources; (d) It has an appearance and quality of a product that conform to the market demand, (e) It has a market niche, both domestic and international; (f) It has a high economic value; (e) It can become a source of income for the local economy.

Relatively a lot of the community learners work in creative economy sector especially in handicraft which needs and is urgent to be considered.

\section{METHODS}

This study used qualitative research design. This study was conducted in two villages, namely, Tembok village, Tejakula district, Buleleng regency, and Abang village, Abang district, Karangasem regency with the subjects especially focused on community learners. The data collection was done through observation, interview, documentation. The observation was conducted on process of making handicrafts conducted by the community learner. Then, it was continued into interview where 5 respondents were involved in this method. The last method, documentation, was conducted by taking pictures of the process and the handicrafts resulted by the community learner. All of the data in this study was of qualitative type where these data was analyzed by using Huberman and Mile's model analysis [7] which contains data reduction, data display, data interpretation, and drawing conclusion. Among all the data, almost all of them were used in this study. Then, the data was described qualitatively. Due to the next step, the data was interpreted to get the meanings of it. Finally, the conclusion of the data could be drawn.

\section{FINDINGS AND DISCUSSIONS}

The creative economy products of the community learners which have a great potential to be developed into superior products through One Village One Product in the two villages, namely Tembok village and Abang village can be described as follows.

\section{A. Ingke Lidi Pohon Lontar ( Palm Leaf Rib) in Tembok Village}

One of the creative economy activities done by the community learners that become a reliable product in Tembok village, Tejakula district, is ingke lidi pohon lontar (palm leaf rib) handicraft. Initially, the motif and design of inke lidi lontar in Tembok village were monotonous and the product was only sold in the local market. In terms of product it did not have a special characteristic which was different from that from other villages. In rainy season, ingke from Tembok village changed color into yellow since it did not have enough sunlight. This is because in rainy season the temperature drops and it becomes humid. This causes ingke to become infested by mold. A good strategy to heat palm leaves is to put them in a room at a relatively high temperature.

Hence the researchers together with community learners developed new motifs and designs which are more varied so that they have a higher price and they are not only for local consumption.

The research team also offered a chemical substance for the preservation of ingke which has no side effect. In addition, some anti-bacteria substances were also tried to preserve ingke handicraft in rainy season so that it can still be used and is able to become a good material for ingke handicraft. After giving them a training and capacity building in the matter that is related to ingke (palm leaf rib) handicraft products in Tembok village, Tejakula village, became more interesting in its appearance, color and flexibility compared to other places. In addition, ingke handicraft has also been extended to the production of other products such as lampion, a container to hold cakes, etc. Actually, creative economy in Tembok village is very potential and is supported by the availability of its raw material. In addition, it can be used as a tourism souvenir from North Bali and East Bali.

What follows are various photographs of ingke handicraft products made by the community learners from Tembok village.

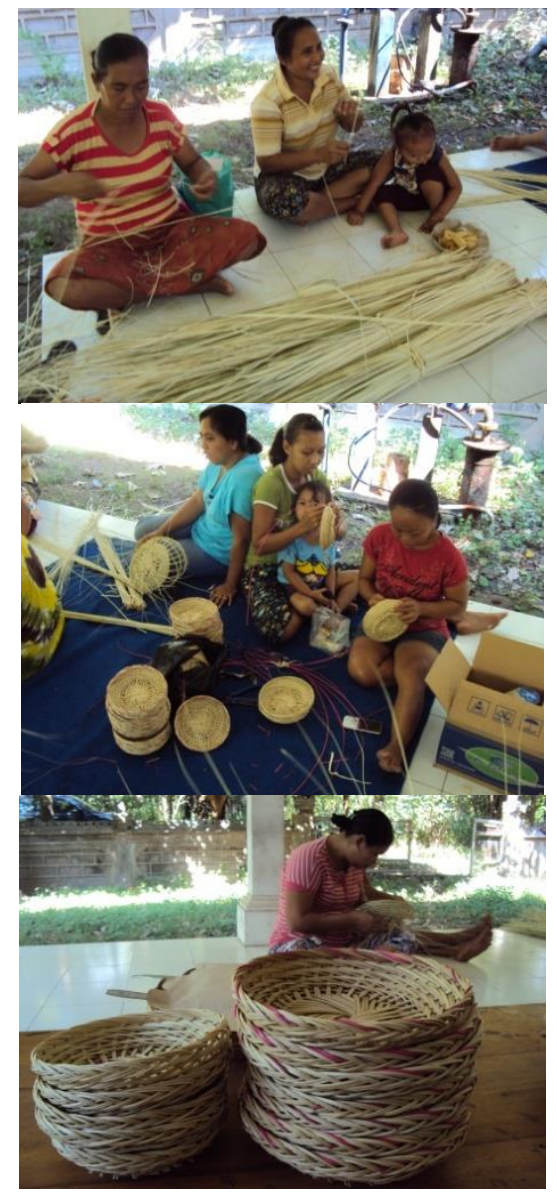

Fig. 1. Ingke handicraft products made by the community learners from Tembok village 
B. Coconut Shell Handicraft in Abang Village, Karangasem

In Waliang village, Karangasem, coconut shells can be used as the materials for making various handicrafts both functional and decorative ones such as fruit container, tamas ( a kind of plate, sokasi, etc. They are bought by many people for their good appearance and because it is environmentally friendly to use them. The use of coconut shells for making various handicrafts helps in preservation of the environment since it reduces waste from coconut processed product production, especially in Karangasem where many coconuts grow. Thus, theoretically, the coconut shell handicrafts should be produced at a high level of continuity and they still can develop at a larger scale.

To obtain the raw material the craftsmen and craftswomen do not need to damage the environment since in Bali, especially in Karangasem there are so many coconut trees that they do not have any problem with the raw material. Although in practice sometimes the raw materials have to be obtained from Klungkung. Because of the abundance in number and the coconut shells have not yet been processed optimally, before the coconut shells were only used as fire woods.

One of the craftsmen in Abang district is I Komang Eka Lestari who is the pioneer in developing the coconut shell crafts. Outside Bali there are many coconut shell crafts but the coconut shell crafts from Waliang village has its own unique characteristics. The coconut shell crafts in this area are processed by plaiting the coconut shells. Before that the coconut shells are cut into small circles like ancient Bali coins (uang kepeng). When the plaiting is finished the crafts are painted with varnish to make them shine and the products last long.

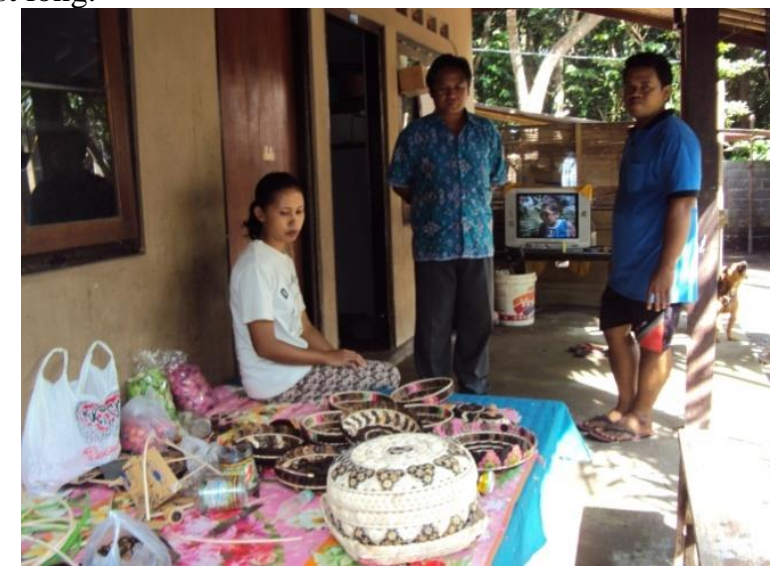

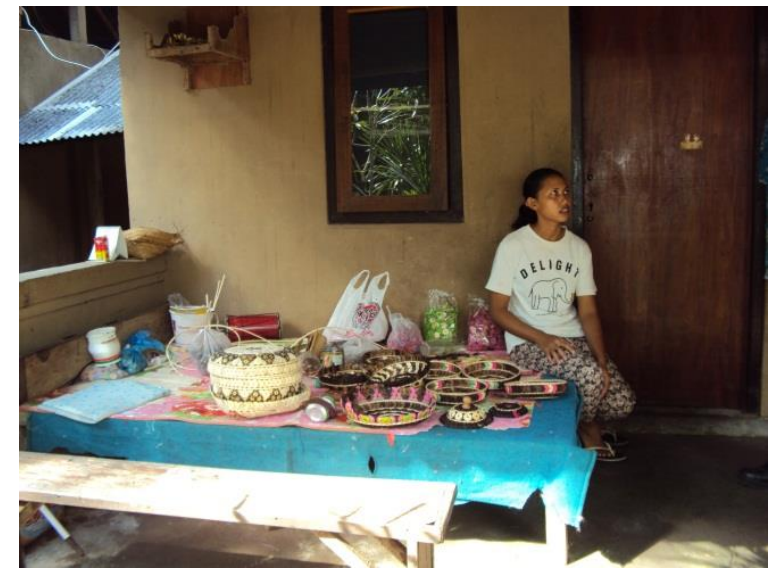

Fig. 2. Coconut shell handicrafts from Abang village, Karangasem

\section{CONCLUSION}

The creative economy of the community learners has developed well since it has been managed well, with the touch of people from a university, and the support from the existing potentials in the village. Since it is supported by the village potentialities, it is getting more and more developed. At the initial stage innovations and design development tended to be monotonous, but after a training and capacity building were implemented, and after the artistic touch from the university, at last, a design innovation could be done. The development of an innovative design can add the selling value of the product made by the craftmen. In addition, a broader marketing strategy has been able to be used by the craftsmen with the help from the researchers. Through a limited group discussion, a memorandom of understanding could be signed by the craftsmen and the local government, which was facilitated by Universitas Pendidikan Ganesha. Even group consolidating has been organized by the craftsmen to look for the possibility to obtain assistence in the form of facilities and marketing from the local government. The dominant handicrafts produced are ingke, lamp stand from palm leaf ribs, photo frame, and a container to hold offerings from coconut shells. Some products made by the craftsmen have been displayed in exhibitions with local and national scales.

\section{REFERENCES}

[1] Suparwoko, 2010, Pengembangan Ekonom iKreatif Sebagai Penggrak Industri Pariwisata, Simposium Nasional 2010: Menu Purworejo Dinamis dan Kreatif

[2] Sujana, Edy. 2012. Pengembangan Ekonomi Kreatif Warga Belajar dalam Mendukung Kepariwisataan di Provinsi Bali. Singaraja: Undiksha (Laporan Penelitian MP3EI)

[3] Sujana, Edy. 2013. Pengembangan Ekonomi Kreatif Warga Belajar dalam Mendukung Kepariwisataan di Provinsi Bali. Singaraja: Undiksha (Laporan Penelitian MP3EI)

[4] Apri Nuryanto, Penny Rahmawaty, Sutopo, Paryanto, 2010 Peningkatan Produksi Kelompok Pengrajin Kipas di Jipangan Melalui Konsep Proses Produksi Terpadu 
[5] Heny Prananingrum, 2009, Perkembangan Desain dan Proses Produksi Kerajinan Kayu di Desa Batokan Kasiman Bojonegoro, Jurusan Seni Rupa, Fakultas Bahasa dan Seni, Universitas Negeri Semarang, Semarang.

[6] Departemen Perdagangan Republik Indonesia.2008. "Pengembangan Ekonomi Kreatif Indonesia 2025 : Rencana Pengembangan Ekonomi Kreatif Indonesia 2009 - 2025"

[7] Huberman, A.B dan Miles M.B. 1992. Analisis Data Kualitatif. (Terjemahan). Jakarta: UI Press.

[8] Badan Pusat Statistik. 2010. Bali Dalam Angka 2010

[9] Direktorat Pembinaan Pendidikan Masyarakat Dirtjen Pendidikan Anak Usia Dini, Nonformal dan Informal
Kemdiknas.2011. Keaksaraan dasar dan Keaksaraan Usaha Mandiri. Jakarta: Kemdiknas.

[10] Departemen Kebudayaan dan Pariwisata Republik Indonesia. 2009. Undang-Undang Republik Indonesia No. 10 Tahun 2009 tentang Kepariwisataan.

[11] Pangestu, Mari Elka.2008. "Pengembangan Ekonomi Kreatif Indonesia 2025”, disampaikan dalam Konvensi Pengembangan Ekonomi Kreatif 2009-2015 yang diselenggarakan pada Pekan Produk Budaya Indonesia 2008, JCC, 4 -8 Juni 2008.

[12] Kementerian Koordinator Bidang Perekonomian. 2011. PokokPokok Masterplan Percepatan dan Perluasan Pembangunan Ekonomi Indonesia tahun 2011-2025 disampaikan dalam Rakernas Kementerian KUKM tanggal 14 Mei 2011 di Jakarta. 